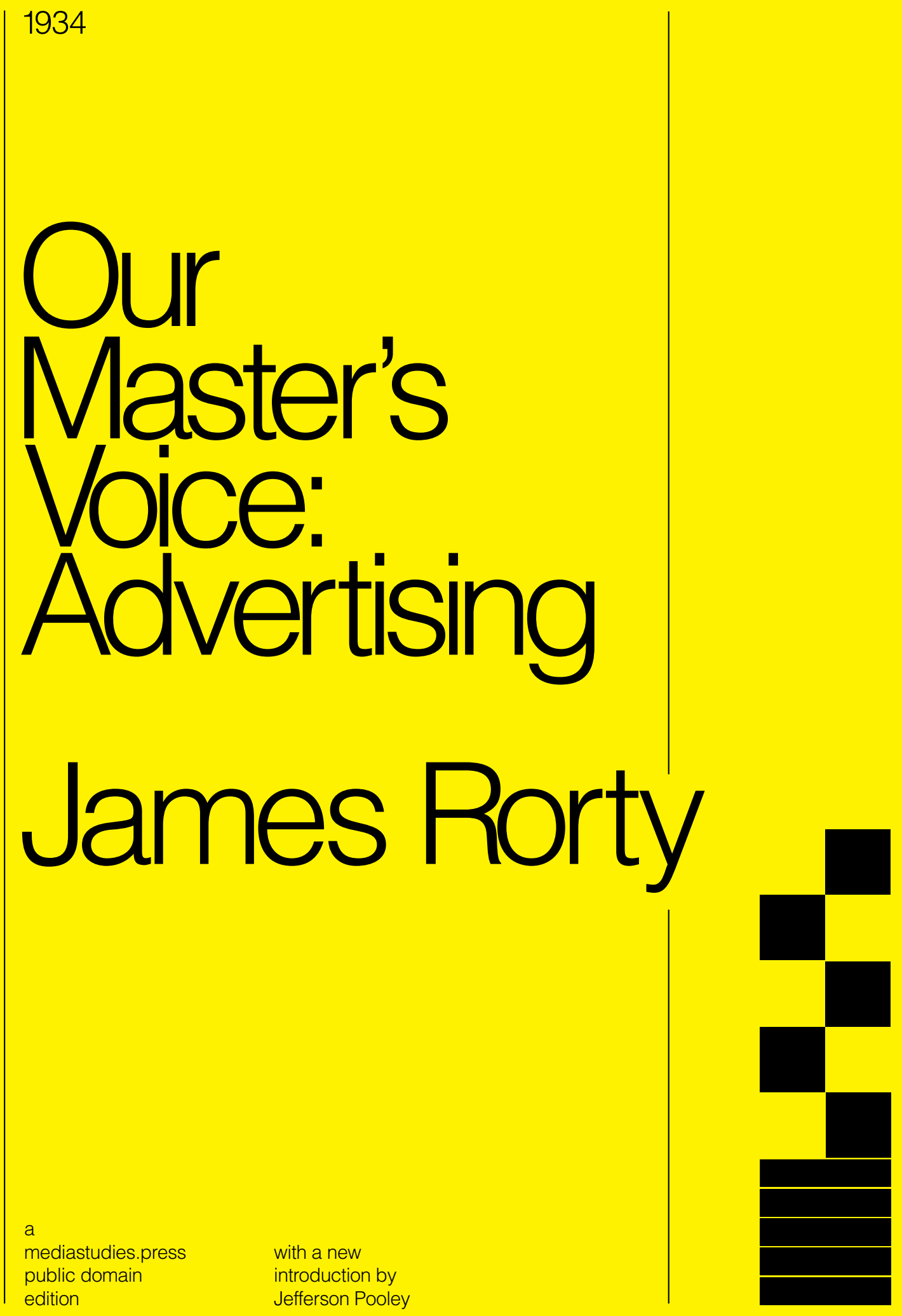




\section{James Rorty}

OUR MASTER'S VOICE

ADVERTISING 
Our Master's Voice: Advertising, originally published in 1934 by the JOHN DAY COMPANY, is in the public domain.

Published by mediastudies.press in the public domain series

mediastudies.press I 414 W. Broad St., Bethlehem, PA 18018, USA

New materials are licensed under a Creative Commons Attribution-Noncommercial 4.0 (CC BY-NC 4.0)

COvER DeSIgN: Mark McGillivray

CREDIT FOR SCAN: Internet Archive, contributor Prelinger Library, 2006 upload

CREDit FOR LATeX template: Book design inspired by Edward Tufte, by The Tufte-LaTeX Developers

ISBN 978-1-951399-00-9 (print) I ISBN 978-1-951399-01-6 (ebook)

DOI $10.21428 / 3 \mathrm{f} 8575 \mathrm{cb} . d b b a 9917$

LIBRARY OF CONGRESS CONTROL NUMBER 202094177

Edition 1 published in October 2020 


\section{ALL FOR PURITY}

THERE are no interested, profit-motivated lobbyists at Washington;

doi I original pdf

only patriots, crusaders, guardians of our most sacred institutions, saviors of humanity. If you doubt this, read the transcript of the public hearings held December 7 and 8 in Washington on the TugwellCopeland Food and Drug Bill. If, after that, you are still cynical, you should read the mail the President, General Johnson, and Postmaster Farley received from the patriotic medicine men, vitamin men, and cosmeticians whose sole concern appeared to be the welfare of the present Administration and the NRA. The names of these correspondents cannot be divulged, but here are a few samples of their style:

With yourself and every other loyal citizen of the United States endeavoring to assist in the relief of unemployment, it would seem that any type of legislation that would retard the recovery of business would be unfortunate at this time. Therefore, House Bill 6110 and the Copeland Bill should be given serious consideration as their effect upon an enterprise with an annual output of over $\$ 2,000$,ooo would be serious indeed....

We have no objections to regulation but ... here is no ordinary regulator measure of the industry. Here is a bill known as the Tugwell Bill ... that openly demands that the Secretary of Agriculture in enforcement of regulations be final and absolute and without appeal to the courts.... Now I'm no disgruntled manufacturer writing you; I'm quite well able to take care of myself and have been doing it in this business for many, many years....

Practically all the worth-while factors in proprietary cosmetic, drug, food, and advertising industries are in accord that these Tugwell measures are impossible of amendment and should be withdrawn....

I have recently been impressed with the danger to the Administration that is resulting from the agitation created by what is known as the Tugwell Bill....

There are four main points to note about this huge correspondence, of which only a few typical examples have been excerpted: (1) that the names of most of the ready letter-writer firms are already 
familiar through notices of judgment issued by the Food and Drug Administration at the termination of cases brought under the present inadequate law, in Post Office fraud orders or in the Federal Trade Commission cease-and-desist orders; (2) that the writers invoke the principle of "recovery" as opposed to "reform" in order to defend businesses which in most cases are demonstrably a danger and a burden to both the public health and the public pocketbook; (3) that they do not hesitate to misrepresent both the nature and effects of the bill, as for example by asserting that Administration action would not be subject to court review although such review would be easily available to defendants under both the original bill and the present revised Copeland Bill; (4) that the writers, by implication, threaten the Administration with a political headache and political defeat, regardless of the merit of the issues involved.

The nature and methods of this lobby can best be understood by examining the following "Who's Who" of the leading lobbyists. A complete list is as impossible, as would be any attempt to estimate the expenditure, undoubtedly huge, of the proprietary drug, food, and advertising lobby.

Frank (Cascarets) Blair. Mr. Blair represents the Proprietary Association, the chief fraternal order of the patent-medicine group, but even closer to his heart, one suspects, is Sterling Products. This is a holding company for the manufacturers of such products as Fletcher's Castoria, Midol, Caldwell's Syrup and Pepsin, and Cascarets, a chocolate-covered trade phenopthalein and cascara laxative recently seized by the Food and Drug Administration. The Proprietary Association and Mr. Blair, plus the National Drug Conference, backed the Black Bill, written by Dr. James H. Beal, chairman of the board of trustees of the United States Pharmacopoeia. The Black-Beal Bill would further weaken even the present inadequate law, make seizures practically impossible, and permit nostrum-makers to get away with murder in their advertising. In short, it is a sheer fake.

Hon. Thomas B. (Crazy Crystals) Love. Mr. Love, a former Assistant Secretary of the Treasury, is attorney for the Crazy Water Company of Mineral Wells, Texas, manufacturers of Crazy Crystals, a prominent exhibit last summer in the Food and Drug Administration's well-known "Chamber of Horrors." At the December hearings Mr. Love said, "No harm has ever resulted, or is likely to result, from the misrepresentation of the remedial or therapeutic effect of naturally produced mineral waters," which is a brazen enough falsification. Two kinds of harm result from such misrepresentation-harm to the health of the victim who takes a dose of horse physic under the illusion that a dose of salts is good for what ails him; harm to the victim's pocket-book because he paid about five times as much for that 
dose of salts as it was worth.

H. M. (Ovaltine) Blackett. Mr. Blackett is president of BlackettSample-Hummert, a Chicago advertising agency. His pet account is Ovaltine, that mysterious "Swiss" drink which puts you to "sleep without drugs" and performs many miracles with underweight children, nursing mothers, busy workers and old people. "Food and drug advertising," Mr. Blackett writes to magazine and newspaper publishers, "is different from other classifications. It must actually sell the product. It must put up a strong selling storystrong enough to actually move the goods off the dealers' shelves." More briefly, Mr. Blackett believes it would be impossible to sell a "chocolate-flavored, dried malt extract containing a small quantity of dried milk and egg" for what it really is—at least for a dollar a can.

William P. (Jacob's Ladder) Jacobs. Mr. Jacobs is president of Jacobs' Religious List, which would appear to represent the alliance of the fundamentalist business and the proprietary-medicine business. As a publishers' representative of the "official organs of the leading white denominations of the South and Southeast," he offers a combined weekly circulation of 300,317 to the God-fearing manufacturers of Miller's Snake Oil (makes rheumatic sufferers jump out of bed and run back to work), kidney medicines, rejuvenators ("Would you like to again enjoy life?"), contraceptives (presumably for an equally holy purpose), reducing agents and hair-growers. Mr. Jacobs is secretary and general manager of the Institute of Medicine Manufacturers; he is, in fact, a member of the old Southern patent-medicine aristocracy. His father, J. F. Jacobs, was author of a profound treatise on "The Economic Necessity and the Moral Validity of the Prepared Medicine Business."

J. Houston Goudiss. Mr. Goudiss appears to be the missing link in the menagerie of medicine men, vitamin men, and ad-men who crowd the big tent of the Washington lobby and do Chautauqua work in the field. On November 16th last he appeared before the convention of the New York State Federation of Women's Clubs, donned the mantle of the late Dr. Harvey W. Wiley, and begged his hearers to oppose the Tugwell Bill. He said in part:

So far as I am known to the American public, I am known as a crusader for the better health of our people.... Early in my career I came under the benign influence of the late Dr. Harvey W. Wiley. I was privileged to support him in his work ... Were Dr. Wiley alive today, I am sure that he would be standing here instead of me. And if I presume to wear his mantle, it is because I feel that the great urgency of the situation calls upon me to do so.... When I was first informed that our Congress was ready to consider a new pure food and drugs law ... I was exultant.... Later when I read the proposed law ... my heart fell with foreboding. I recognized it as only another overzealous measure 
like our unhappy Eighteenth Amendment and the Volstead Act.... The Tugwell Bill is fraught with danger....

About that Harvey W. Wiley mantle the widow of Dr. Wiley, in the course of an eloquent plea for the Tugwell Bill at the December hearing, said: "I have never heard Dr. Wiley mention Mr. C. Houston Goudiss, and inquiry at the Department of Agriculture discloses the fact that no correspondence between Dr. Wiley and Mr. Goudiss between 1905 and 1911, when Dr. Wiley resigned, is on file."

And now about Mr. Goudiss himself: He publishes the Forecast, a monthly magazine full of vitamin chatter not unrelated to Mr. Goudiss's activities as broadcaster over Station WOR for various and sundry food products. He is author of Eating Vitamins and other books also of a signed advertisement for Phillips' Milk of Magnesia. His Elmira speech was promptly sent out as a press release by the Proprietary Association, and he also fought the Tugwell Bill over the radio.

The organizational set-up of the drug men, the food men, the medicine men, and the ad-men is almost as complicated as that of the Insull holding companies. At the top sits the High Council of the Drug Institute, an association of associations, formed originally to fight the cut-rate drug stores. The Proprietary Association, the Institute of Medicine Manufacturers, and the United Medicine Manufacturers, all have booths in this big tent. The last-named organization came right out in the open, whooping, yelling, and rattling the wampum belt. The Food and Drug Administration knows them well, and the public would know them better if this department of government were authorized by law to publicize its files. Here are a few of the most eminent and vocal patriots and purity gospelers:

President J. M. (Toma Tablets) Ewing. Toma Tablets are innocuously labeled, but advertised for stomach ulcers, The advertising clause of the Copeland Bill is what is worrying Mr. Ewing.

Vice President I. R. (Health Questions Answered) Blackburn. Mr. Clinton Robb, the legal magician for the U. M. M.A., fixed up the labels of the Blackburn products, which rejoice in a string of notices of judgment. These products are sold through an advertising column headed "Health Questions Answered." You write to Dr. Theodore Beck, who answers the questions in this column, and the good doctor informs you that one or more of the Blackburn products is good for what ails you. It's as simple as that.

Vice President George Reese is at present slightly handicapped in selling venereal-disease remedies by the seizure by the Food and Drug Administration a month ago of one of his nostrums-not the first action of this kind, judging by the notices of judgment against this firm. 
Vice President Earl E. (Syl-vette) Runner can boast a dozen or more notices of judgment against his many products, the most prominent of which, Syl-vette, was seized only a short time ago. This "reducing agent" is a cocoa-sugar beverage that keeps your stomach from feeling too empty while a diet does the slenderizing.

D. A. (Gallstones) Lundy, of the Board of Managers of the U. M. M. A., advertises: “Gallstones. Don't operate. You make a bad condition worse. Treat the cause in a sensible, painless, inexpensive way at home." But, alas, the proposed new law forbids the advertising of any drug for gallstones, declaring the disease to be one for which self-medication is especially dangerous. Perhaps this explains Mr. Lundy's fervid letters to Senators demanding the dismissal and prosecution of Chief Campbell of the Food and Drug Administration on the ground that the latter has been improperly spending the Federal Government's money for propaganda.

William M. (Nue-Ovo) Krause, of the membership committee of the U. M. M. A. Mr. Krause's Research Laboratories, Inc., of Portland, Oregon, labeled Nue-Ovo as a cure for rheumatism until 1929 when the Food and Drug Administration seized the product and forced a change of the label. Nue-Ovo is still widely advertised in the West as a cure for rheumatism and arthritis.

Kenneth (Vogue Powder) Muir, of the Board of Managers of the U. M. M. A. When Mr. Muir's Vogue Antiseptic Powder was seized in 1930, it was being recommended not only for genito-urinary affections of men and women but also in the treatment of diphtheria.

T. S. (Renton's Hydrocine Tablets) Strong, of the Board of Managers of the U. M. M. A., is a partner in Strong, Cobb \& Company of Cleveland, pharmaceutical chemists who manufacture products for other concerns. There are notices of judgment against venereal-disease remedies and a contraceptive manufactured by them. This firm also makes Renton's Hydrocine Tablets, a cinchophen product sold for rheumatism to which, according to the American Medical Association, many deaths have been directly traced.

C. C. (Kow-Kare) Parlin. For months now Mr. Parlin, research director of the Curtis Publishing Company, assumed much of the task of mobilizing and directing the heterogeneous but impassioned hosts of purity gospelers that fought the Tugwell Bill. Mr. Parlin is a statistician, a highbrow, and no end respectable. Moreover, he represents, indirectly at least, the Ladies' Home Journal and the Country Gentleman. In their February, 1934, issues both of these Curtis properties published editorials, written in language strikingly similar to Mr. Parlin's recent speeches and signed writings, to the effect that in their advertising pages they had struggled to be pure-well, pure enough-and that the new bill was just painting the lily. 
How pure is pure? The February issue of the Country Gentleman contains advertisements of several products which would be subject to prophylactic treatment if an effective law against misleading advertising were passed. The February issue of the Ladies' Home Journal, which says that for more than a generation it has "exercised what we consider to be proper supervision over all copy offered for our pages," contains advertisements of at least eight products whose claims would require modification if the proposed bill became law. The Ladies' Home Journal's "pure-enough" list includes Pepsodent, Fleischmann's Yeast, Ovaltine, Listerine, Vapex, Musterole, Vicks Vapo Rub, and Pond's creams. In addition to some of the foregoing, the Country Gentleman stands back of advertisements of Ipana, Toxite, Sergeant's Dog Medicines, Bag Balm, and Kow-Kare. Concerning the last-named product, the fact-minded veterinary of the Food and Drug Administration comments as follows:

This used to be sold as Kow-Kure, which purported to be a remedy for contagious abortion, until trouble threatened with the Pure Food and Drug Administration. No drug or combination of drugs has any remedial value in treating contagious abortion. The danger of these nostrums is that the farmer relies upon them.

There is one obvious lack in the foregoing list of purity gospelers. It includes no women. We therefore hasten to present Gertrude B. Lane, editor of the Woman's Home Companion.

In the Woman's Home Companion's "index of products advertised," the statement is made that "the appearance in Woman's Home Companion is a specific warranty of the product advertised and of the integrity of the house sponsoring the advertisement." Why, then, did Miss Lane oppose the bill? Was she alarmed by the fact that the Woman's Home Companion publishes as pure some of the same misleading advertisements that appear in the Ladies' Home Journal, already referred to, and that would be embarrassed by the advertising provision of the Copeland Bill? It is a great industry: women editors, publication statisticians, ad-men, vitamin men, medicine men, cosmeticians, all in the same boat and rowing for dear life against a rising tide of public opinion which demands that this grotesque, collusive parody of manufacturing, distributing and publishing services be compelled to make some sort of sense and decency no matter how much deflation of vested interests is required. 